\title{
No Traces of SARS-CoV-2 In Wounds of COVID-19 Positive Patients: A Pilot Study
}

\author{
Sunil Gaba ${ }^{1}$ Gowtham Kampalli ${ }^{1}$ Kapil Goyal ${ }^{2}$ Vikas Suri ${ }^{3}$ Poonam Chauhan ${ }^{2}$ \\ Shyam C. Meena ${ }^{4}$ Ankur Bhatnagar ${ }^{5} \quad$ Mini P. Singh ${ }^{2} \quad$ Ramesh K. Sharma ${ }^{1}$
}

${ }^{1}$ Department of Plastic Surgery, PGIMER, Chandigarh, India

2Department of Virology, PGIMER, Chandigarh, India

${ }^{3}$ Department of Internal Medicine, PGIMER, Chandigarh, India

${ }^{4}$ Department of Anaesthesia, PGIMER, Chandigarh, India

${ }^{5}$ Department of Plastic Surgery, SGPGI, Lucknow, Uttar Pradesh, India

\begin{abstract}
Address for correspondence Sunil Gaba, Department of Plastic Surgery, PGIMER, Sector-12, Chandigarh 160012, India (e-mail: drsgaba@gmail.com).
\end{abstract}

\begin{abstract}
Keywords

- COVID-19

- rRT-PCR

- wound swab

- SARS-Cov-2 virus

Background This study was performed to investigate the presence of SARSCoV-2 virus in wounds of COVID-19 positive patients.

Methods This is a single-center observational study. COVID-19 patients with wounds (traumatic/infective/surgical) were included in this study. Preoperative, intraoperative, or postoperative specimens were collected and analyzed with real-time reverse transcriptase polymerase chain reaction (rRT-PCR) to know the presence of the virus.

Results A total of eight patients were included in this study. Eleven samples were collected (seven wound swabs, two peritoneal fluids, and two tissue specimens) and analyzed. None of the samples from the wound tested positive for the virus while they were tested positive for nasal swab taken simultaneously or within 3 days prior.

Conclusion The wounds of COVID-19 patients are considered negative and can be managed with routine wound precautions.
\end{abstract}

\section{Introduction}

Coronavirus disease 2019 (COVID-19) is primarily an acute respiratory syndrome caused by the novel SARS-CoV-2 virus. This disease emerged in China, became a pandemic in a short time, and has proved fatal with high number of mortalities. ${ }^{1}$ The most common presenting symptoms are malaise, fever, shortness of breath, and features of pneumonia in severe cases. The COVID-19 primary transmission route is through person-to-person contact and through direct contact with respiratory droplets generated when an infected person coughs or sneezes. The real-time reverse transcriptase polymerase chain reaction (RT-PCR) of the nasal swabs is the most reliable method of detection. As of now other methods of transmission are not proven. Health care workers are at high risk due to their involvement in patient care and handling of tissues. The role of the blood-borne transmission is uncertain; in one study done by Chang et $a{ }^{2}{ }^{2}$ they found the virus in four blood samples of asymptomatic blood donors. We studied the wounds of COVID-19 patients to detect the presence of virus and risk of transmission.

\section{Method}

This study was performed in the Department of Plastic Surgery in collaboration with the Department of Virology, PGIMER, Chandigarh, an apex tertiary center and special COVID-19 hospital. In the present study, wound specimens from COVID-19 confirmed patients were collected for studying the presence of SARS CoV-2 RNA by rRT-PCR assay to study the possible transmission of SARS CoV-2 from open wounds. The study was conducted after obtaining the clearance from institutional ethical committee.

\section{published online} October 16, 2020
DOI https://doi.org/ $10.1055 / \mathrm{s}-0040-1718852$ ISSN 0970-0358.
(C) 2020. Association of Plastic Surgeons of India.

This is an open access article published by Thieme under the terms of the Creative Commons Attribution-NonDerivative-NonCommercial-License, permitting copying and reproduction so long as the original work is given appropriate credit. Contents may not be used for commercial purposes, or adapted, remixed, transformed or built upon. (https://creativecommons.org/licenses/by-nc-nd/4.0/).

Thieme Medical and Scientific Publishers Pvt. Ltd. A-12, 2nd Floor, Sector 2, Noida-201301 UP, India 


\section{Sample Collection}

COVID-19 confirmed patients with open wounds/surgical wounds were included in the present study. Nasal swabs and throat swabs were collected from all the patients who presented to the emergency as a part of routine screening for SARS-CoV-2. Specimens from wounds were collected within 3 days of admission or simultaneously. A total of 11 samples were collected in viral transport media (VTM) either preoperatively, intraoperatively, or after the surgery. Tested specimens include swabs from wounds (traumatic and infective), wound tissue, peritoneal fluid and intestinal tissue of abdominal emergencies. The samples were collected and transported by dedicated COVID-19 duty personnel. All precautions were taken to maintain the cold chain of specimen transport. Adequate care was taken to prevent the delay between the collection time and processing time. All specimens were tested with rRT-PCR ( - Fig. 1).

\section{RNA Extraction}

All the samples were processed in Biosafety cabinet class II using safety precautions. The total RNA was extracted from $140 \mu \mathrm{L}$ of a sample using QIAamp Viral RNA extraction kit (Qiagen, Germany), according to the manufacturer's

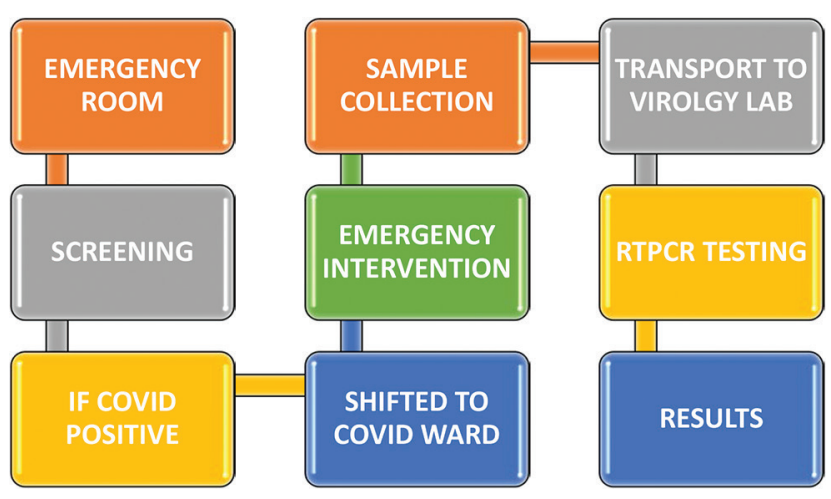

Fig. 1 Protocol for wound swab in COVID positive patients. instructions. Finally, the RNA was eluted in $60 \mu \mathrm{L}$ of elution buffer and stored at $-20^{\circ} \mathrm{C}$ till further use.

\section{Real-time Reverse Transcriptase PCR (rRT-PCR)}

SARS-CoV-2 RNA was detected by using TaqPath COVID-19 Combo Kit ("TaqPath kit": Applied Biosystems, Foster City, California, USA) where nucleocapsid (N), spike (S), open reading frame (ORF-1ab) genes, and internal control were targeted by rRT-PCR.

\section{Results}

Eleven specimens were studied from eight patients. All were male patients. The mean age was 39 years. Most of the patients were mildly symptomatic for COVID-19 illness, and some were asymptomatic. Samples include seven wound swabs, two peritoneal fluid samples, and two tissue samples (-Table 1). All samples were tested in an in-house virology laboratory with rRT-PCR. None of the samples tested positive for the SARS-CoV-2 virus.

\section{Discussion}

In our study, we found the COVID-19 virus is not present in the acute wounds of the patient where patient nasal and throat swabs are still positive for the virus. Wang et $\mathrm{al}^{3}$ studied 1070 specimens from 205 patients, and they found the presence of the virus predominantly in the lower respiratory tract swabs; a small percent of fecal and blood samples also showed the presence of a live virus. They suggested an extrapulmonary route of spread could be the cause of the rapid spread of disease. Zhang et $\mathrm{al}^{4}$ in their study found the virus in oral swabs, anal swabs, and blood, which suggested a possible feco-oral, body fluid transmission. Cuvler et $\mathrm{al}^{5}$ first published the presence of coronavirus in the ascitic fluid. We studied the abdominal emergencies in our study, including wound swab, peritoneal fluid, and bowel tissues, but none tested positive

Table 1 Results of specimens tested by the rRT-PCR

\begin{tabular}{|c|c|c|c|c|c|c|}
\hline & Age & Sex & Diagnosis & \multicolumn{2}{|c|}{ Sample studied } & RT-PCR result \\
\hline Patient 1 & 23 & Male & RTA with degloving injury thigh & Wound swab & - & Negative \\
\hline Patient 2 & 28 & Male & Anterior abdominal wall abscess & Wound swab & - & Negative \\
\hline Patient 3 & 75 & Male & Intestinal obstruction k/c/o SCC anal canal & Peritoneal fluid & Resected bowel & Negative \\
\hline Patient 4 & 35 & Male & Perforation peritonitis & Wound swab & Peritoneal fluid & Negative \\
\hline Patient 5 & 46 & Male & RTA with crush injury right foot & Wound swab & Tissue & Negative \\
\hline Patient 6 & 25 & Male & Perforation peritonitis & Wound swab & - & Negative \\
\hline Patient 7 & 37 & Male & Necrotizing fasciitis thigh & Wound swab & - & Negative \\
\hline Patient 8 & 32 & Male & Necrotizing fasciitis thigh & Wound swab & - & Negative \\
\hline
\end{tabular}

Abbreviations: k/c/o SCC, known case of squamous cell carcinoma; RTA, road traffic accident; rRT-PCR, real-time reverse transcriptase polymerase chain reaction. 
for the virus. Out of necessity, the goal of wound care during COVID-19 illness has been shifted to prevent serious complications and minimize hospital stay and surgical interventions. Although the wound is not positive, strict precautions need be followed during the course of patient care when throat and nasal swabs are still positive. With the daily increase in new cases, there is an ongoing burden on these dedicated COVID-19 hospitals for new beds and more health care workers. Patients with wounds whose throat swabs are negative can be referred back to their regional health centers to decrease the burden on COVID-19 hospitals.

The limitation of this study is it needs a large sample size to confirm virus absence in the wounds.

\section{References}

1 Zhu N, Zhang D, Wang W, et al; China Novel Coronavirus Investigating and Research Team. A Novel Coronavirus from Patients with Pneumonia in China, 2019. N Engl J Med 2020;382(8):727-733

2 Chang L, Zhao L, Gong H, Wang L, Wang L. Severe Acute Respiratory Syndrome Coronavirus 2 RNA Detected in Blood Donations. Emerg Infect Dis 2020;26(7):1631-1633

3 Wang W, Xu Y, Gao R, et al. Detection of SARS-CoV-2 in Different Types of Clinical Specimens. JAMA 2020;323(18):1843-1844

4 Zhang W, Du RH, Li B, et al. Molecular and serological investigation of 2019-nCoV infected patients: implication of multiple shedding routes. Emerg Microbes Infect 2020;9(1):386-389

5 Culver A, Arbelot C, Bechis C, Cassir N, Leone M. First description of SARS-CoV-2 in ascites. IDCases 2020;21:e00836

\section{Conflicts of Interest}

None declared. 